\title{
NON-AGENDA
}

With the view of causing an increase to take place in the mass of national wealth, or with a view to increase of the means either of subsistence or enjoyment, without some special reason, the general rule is, that nothing ought to be done or attempted by government. The motto, or watchword of government, on these occasions, ought to be - Be quiet. . . Whatever measures, therefore, cannot be justified as exceptions to that rule, may be considered as non-agenda on the part of government.

\section{Believe It or Not: New Evidence on the Effects of Minimum Wages}

\author{
Judith Sloan
}

0

OME propositions in economics are essentially settled. Consumption rises with income. Public goods are under-produced if left to private transactions. Tariffs lower national income. Higher minimum wages reduce employment.

Higher minimum wages reduce employment? Not so, it would seem, according to a number of economists, chief among them David Card and Alan Krueger, who now dispute the proposition that higher minimum wages lead to lower employment, particularly of those employed at or around minimum wage levels. Rather, they claim, increases in minimum wages, at least relatively small ones, can have positive employment effects, including for low-skilled workers.

Needless to say, this new research has sensational political implications. Governments need not worry about the sensitive trade-off between equity and adverse employment consequences when considering rises in statutory minimum wages. Trade unions can point to the positive employment generation that will follow from their campaigns to raise minimum wages.

Should we accept this new research? Or should we continue to hold on to the conclusions about the impact of minimum wage that were widely supported until Card and Krueger hit the scene?

Judith Sloan is Director of the National Institute for Labour Studies at The Flinders University of South Australia. 


\section{The Minimum Wage Debate: Pre-Card and Krueger}

The debate about the impact of minimum wages was largely resolved until a symposium was held at Cornell University in 1991, titled 'New Minimum Wage Research'. Key among the settled findings was that higher minimum wages lead to lower employment, particularly of low-productivity workers. Certainly, estimates of the minimum wage elasticity of demand varied widely, with some as low as negative 0.1 to others well above negative one. But as Hamermesh (1986:463), in the key reference on labour demand, concluded, there is an '... apparently general inverse relationship between a group's average skill level and the elasticity for its labor'. In other words, for low-skill workers, their own wage elasticity of demand is higher than for high skill workers. Even so, some commentators maintained that minimum wage effects are over-rated, not least because most workers (in the US) have earnings well in excess of the relevant statutory minimum wage (see Brown, Gilroy \& Kohen, 1982; Brown, 1988).

An important development in the debate was the acknowledgment that higher minimum wages can induce lower worker fringe benefits and/or reduce training effort by enterprises. There may be some substitution of higher minimum wages for non-wage benefits. Hashimoto (1982), for example, found that the 1967 hike in the minimum wage in the US led to workers gaining 32 cents an hour in monetary compensation but losing 41 cents an hour in training. Fleisher's (1981) study of the US retail industry established that higher minimum wages were linked to reductions in fringe benefits and a deterioration in working conditions.

\section{The Minimum Wage Debate: Post-Card and Krueger}

The key papers presented at the Cornell Seminar were Katz and Krueger (1992), Card (1992a) and Card (1992b). A fourth key paper about fast-food restaurants in New Jersey and Pennsylvania (Card \& Krueger 1994) is arguably the most influential of the four papers. ${ }^{1}$

The Card (1992a) study uses regional variations in wages to assess the effect of the April 1990 rise in the US federal minimum wage on teenage wages, employment and participation in education. Because the rates of increase in teenage pay differed widely across the states, Card predicts that employment losses would be concentrated in low-wage states. His results in fact point to the opposite: 'there is no evidence that the rise in the minimum wage significantly lowered teenage employment rates or altered school enrollment patterns' (Card 1992a:36).

In Card (1992b), the author uses the case of California between 1987 and 1989 to address the question: do minimum wages reduce employment? Georgia, Florida, New Mexico, Arizona and Dallas/Fort Worth, where minimum wages did not cliange, are selected as controls. In California, however, the minimum wage was

\footnotetext{
1 The Card and Krueger (1994) paper is an improved variant of the Katz and Krueger (1992) paper, the latter dealing with Texan fast-food industry but with no controls. The results of Katz and Krueger (1992) are therefore not discussed here.
} 
increased from US $\$ 3.35$ an hour to $\$ 4.25$ in July 1988 . Using information sourced from the Current Population Survey (CPS), the Australian equivalent of the monthly Labour Force survey, Card (1992b:52) concludes as follows:

I find no empirical support for the conventional prediction that economists make regarding the employment effects of minimum wages. Although the rise in the minimum wage in California raised the earnings of the low-wage workers, it does not seem to have significantly reduced employment, even in the retail trade industry.

The Card and Krueger (1994) paper is based on an 'experiment' in New Jersey, where the minimum wage was raised from $\$ 4.25$ an hour to $\$ 5.05$ an hour - a rise of 19 per cent - in 1992, with neighbouring Pennsylvania, where the minimum wage was unchanged, used as the control. From the results of their own 'beforeand-after' telephone survey of establishments in four large fast-food chains (Wendy's, KFC, Roy Rogers and Burger King), the authors conclude from this 'impact study' that employment grew faster in the fast food outlets in New Jersey than in Pennsylvania. Higher minimum wages led to higher, not lower, employment, according to the study.

Finally, it should be noted that there has been some research in the UK on the new minimum wage theories. Dickens, Machin and Manning (1994), for instance, construct a model of the labour market that is general enough to allow higher, lower or unchanged employment as a consequence of higher minimum wages. ${ }^{2}$ Using data on industry based minimum wages set by the UK Wages Councils between 1975 and 1990, the authors conclude that minimum wages have 'compressed the distribution of eamings and probably raised employment' (Dickens, Machin and Manning 1994:29). It should be noted, lowever, that these results contrast markedly with Kaufman (1989) using similar data.

\section{Assessing the Studies}

A number of methodological, theoretical and empirical criticisms can be levelled at the 'New Minimum Wage Research' studies. Welch's (1995) critique of the four US studies raises some very important points. For instance, on Card's (1992a) article, he makes the obvious point that factors other than wages affect employment, with the low-wage states of the south and south-west experiencing rapid employment growth for reasons quite unrelated to the higher federal minimum wage. On Card (1992b), he queries the selection of the controls, as well as pointing to the buoyancy of the Californian economy over the period 1987-89.

Welch (1995) reserves his fiercest criticisms for Card and Krueger's (1994) study of the fast-food industry, noting in particular the ambiguity of the survey questions on employment type and wages. Moreover, in reworking the original data, he

2 The supply of labour to tirms is assumed to be less than perfectly elastic because of baniers to mobility. As a consequence, a degree of monopsony power is conlerred on tirms. 
concludes the results are essentially 'incredible' given the large swings in employment by firm size. Dickens, Machin and Manning (1994:17) argue that ' $\ldots$ impact studies [such as Card \& Krueger (1995)] are not able to add up the employment changes across firms that are due to minimum wages as they have no way of controlling for aggregate industry demand or supply shocks that may be affecting all firms at the same time as the change in the minimum wage'. Moreover, a recent paper by Neumark and Wascher (1995) has cast further doubt on Card and Krueger's (1994) findings. Using comprehensive payroll records, they conclude that the 19 per cent rise in New Jersey's minimum wage reduced employment in the fast-food industry by nearly 5 per cent. Moreover, state-wide data on employment in eating and drinking places are consistent with this finding.

Most economists would query the theoretical basis for the prediction that higher minimum wages raise, not lower, employment. Of course, the case of monopsony - where there is a monopoly purchaser of labour - is clearly recognised as one where a small rise in wages can lead to higher employment, as dominant employers otherwise use their buying power to hold down the price of labour. As long as the minimum wage is set between the monopsony price and the marginal cost of labour, employment will expand. But what is the relevance of monopsony to the cases investigated by Card and Krueger? No one could defend the propositions that all employers in California or the fast-food chains in New Jersey were monopsonists at the time of the studies. ${ }^{3}$ Indeed, Brown, Gilroy and Kohen (1982:489) conclude that 'there is little evidence that [monopsony] is important in modern-day low-wage labor markets'.

There is the possibility, recognised long ago by Stigler (1946), that firms operating below maximum efficiency can be shocked by a higher minimum wage; as a result, higher minimum wages will not necessarily induce lower employment. Whether this 'shock effect' can be repeated many times is, of course, questionable. Another possibility is that minimum wages may be largely non-binding prior to any statutory rise, as the forces of supply and demand dictate wage levels above the minima. Obviously, the impact of an increase in minimum wages in this case is likely to be muted.

\section{Conclusion}

The adverse effect of minimum wages on employment is a proposition that should still be accepted, notwithstanding the recent debate. The studies that have emerged disputing this proposition are weak theoretically, methodologically and empirically. This said, there are instances where higher gross employment following a lifting of minimum wages is possible: where the previous minimum wage was non-binding or

\footnotetext{
${ }^{3}$ To be fair, Card and Krueger (1994:792) argue that '[takenl as a whole, these findings are difficult to explain with the standard competitive model or with models in which employers face supply constraints (e.g., monopsony or equilibrium search models)'. However, Card (1992b:52-3) states that '[in] my opinion, the experiences following the Califonia minimum wage suggest that the [monopsony] model or other alternative models deserve more careful scrutiny'.
} 
demand for labour is increasing rapidly for non-wage reasons. The literature is also clear about the potential for substitution of higher minimum wages for lower fringe benefits and training provision.

To put our main conclusion another way: it would be a brave policy-maker who advocates higher minimum wages, especially to apply to young workers, as a means of reducing unemployment. Even if the own-wage elasticity of labour is relatively low - say minus 0.2 - a 10 per cent rise in the minimum wage applicable to teenagers will induce a 2 per cent fall in their employment. Not only is 2 per cent of a relatively large number also a relatively large number, a 2 per cent rise in employment would be basis for some joy. A 2 per cent fall should therefore be a cause for serious concern.

At the same time, the impact of the recent research on minimum wage effects should not be downplayed. Without doubt, there are valid criticisms of earlier research efforts, not least the specification errors that are now apparent given developments in empirical estimation techniques. There is also the inherent research problem in this area of establishing a data set whereby refutable hypotheses can be tested. The fact that Card and Krueger have made the ruming in this renewed debate means that more updated research will be required to refute convincingly their claims.

Finally, what are the implications for Australia? There is no single statutory minimum wage set by legislators, as is the case in a number of other countries. Rather, a bank of occupational wage minima is set out in awards handed down by arbitral tribunals. In addition, junior rates of pay are laid down in most awards, thereby establishing (minimum) rates of pay according to the age of the worker (generally up to 20 years of age). Because of the pervasiveness of the system (awards cover some 80 per cent of workers), there is virtually no scope for crosssection-based empirical research on the impact of minimum wages. In addition, the most recent Australian time-series based study on own-wage and cross-wage elasticities of labour demand for workers of different ages is now out of date (BLMR, 1983). It should be recalled, however, that for male and female youth workers, the estimated own-wage elasticities were negative and greater than one, leading to the conclusion that 'increases in youth wages relative to those of other groups decrease their demand significantly' (BLMR 1983:91). 


\section{References}

Brown, C. (1988), 'Minimum Wage Laws: Are they Overrated?', Jounial of Economic Perspectives 2(3): $133-45$.

—_ C. Gilroy \& A. Kohen (1982), 'The Effect of the Minimum Wage on Employment and Unemployment', Jounal of Economic Literature 20: 487.528.

Bureau of Labour Market Research (BLMR) (1983), Youth Wages, Employment and the Labour Force, AGPS, Cauberra.

Card, D. (1992a), 'Using Regional Variation in Wages to Measure the Effects of the Federal Minimum Wage', Industrial and Labor Relations Review 46(1): 22-37.

— (1992b), 'Do Minimum Wages Reduce Employment? A Case Study of Califonia', Industrial and Labor Relations Review 46(1): 38-54.

_ \& A. Krueger (1994), 'Minimum Wages and Employment: A Case Study of the Fast-Food Industry in New Jersey and Pennsylvania', American Economic Review 84: 772-93.

Dickens, R., S. Machin \& A. Manning (1994), The Effect of Minimum Wages on Employment: Theory and Evidence from Britain, Cente for Economic Performance, London School of Economics, London (Discussion Paper No. 183).

Fleisher, B. (1981), Minimum Wage Regulation in Retail Trade, American Enterprise Institute, Washington DC.

Hamermesh, D. (1986), 'The Demand for Labor in the Long Run', pp.429-71 in O. Ashenfelter \& R. Layard (eds), Handbook of Labor Economics 1, Elsevier Science Publishers, Netherlands.

Hashimoto, M. (1982), 'Minimum Wage Effect on Training to the Job', American Economic Review 70: 1070-87.

Katz, L. \& A. Krueger (1992), 'The Effect of the Minimum Wage on the Fast-Food Industry', Industrial and Labor Relations Review46(1): 6-21.

Kaufman, R. (1989), 'The Eflects of Statutory Minimum Rates of Pay on Employment in Great Britain', Economic Jounal 99: 1040-53.

Neumark, D. \& W. Wascher (1995), 'The Effect of New Jersey's Minimum Wage Increase on the Fast-Food Employment: A Re-evaluation using Payroll Records', National Bureau of Economic Research, Cambridge, Mass. (NBER Working Paper No. 5224).

Stigler, G. (1946), 'The Economics of Minimum Wage Legislation', American Economic Review 36: $358-65$.

Welch, F. (1995), Review of D. Card \& A. Krueger, Myth and Measurement: The New Economics of the Minimum Wage (Princeton University Press, Princeton, Princeton, 1995), Industrial and Labor Rclations Review 48(4): 842-9. 